\section{Diffusion of Hydroxyl Ions from Calcium Hydroxide and Aloevera Pastes}

\author{
Victor Eduardo de Souza Batista', Douglas Dáquila Olian², Graziela Garrido \\ Mori $^{3}$
}

This study evaluated the diffusion through the dentinal tubules of hydroxyl ions from different calcium hydroxide $(\mathrm{CH})$ pastes containing Aloe vera. Sixty single-rooted bovine teeth were used. The tooth crowns were removed, the root canals were instrumented and the specimens were assigned to 4 groups $(n=15)$ according to the intracanal medication: Group $\mathrm{CH} / \mathrm{S}$ - $\mathrm{CH}$ powder and saline paste; Group $\mathrm{CH} / \mathrm{P}-\mathrm{CH}$ powder and propylene glycol paste; Group $\mathrm{CH} / \mathrm{A}$ - calcium hydroxide powder and Aloe vera gel paste; Group $\mathrm{CH} / \mathrm{A} / \mathrm{P}$ - $\mathrm{CH}$ powder, Aloe vera powder and propylene glycol paste. After placement of the root canal dressings, the teeth were sealed coronally and apically with a two-step epoxy adhesive. The teeth were placed in identified flasks containing deionized water and stored in an oven with $100 \%$ humidity at $37^{\circ} \mathrm{C}$. After $3 \mathrm{~h}, 24 \mathrm{~h}, 72 \mathrm{~h}, 7$ days, 15 days and 30 days, the deionized water in the flasks was collected and its $\mathrm{pH}$ was measured by a $\mathrm{pH}$ meter. The obtained data were subjected to statistical analysis at a significance level of 5\%. The results demonstrated that all pastes provided diffusion of hydroxyl ions through the dentinal tubules. The combination of Aloe vera and $\mathrm{CH}$ (group $\mathrm{CH} / \mathrm{A}$ ) provided a constant release of calcium ions. Group $\mathrm{CH} / \mathrm{A} / \mathrm{P}$ showed the highest $\mathrm{pH}$ at 24 and 72 h. In conclusion, the experimental pastes containing Aloe vera were able to enable the diffusion of hydroxyl ions through the dentinal tubules.

\author{
'Department of Dental Materials and \\ Prosthodontics, Araçatuba School \\ of Dentistry, UNESP - Univ Estadual \\ Paulista, Araçatuba, SP, Brazil \\ ${ }^{2}$ Private Practice, São Paulo, SP, Brazil \\ 3Department of Integrated Clinics, \\ Adamantina School of Dentistry, \\ $\mathrm{FAl}$ - Integrated Colleges of \\ Adamantina, Adamantina, SP, Brazil
}

Correspondence: CD Victor Eduardo de Souza Batista, Rua Engenheiro Kieffer, 674, 16015-050 Osvaldo Cruz, SP, Brasil. Tel: +55-18-35286785. e-mail: victor_edsb@hotmail. com ou victoredsb@gmail.com

Key Words: Aloe vera, calcium hydroxide, dentin, root canal therapy.

\section{Introduction}

Calcium hydroxide $(\mathrm{CH})$ is the standard material for root canal dressing, being widely used in Endodontics (1). This drug was introduced in Endodontics in 1920 by Hermann and has been used in different clinical situations since then (2). The effects of $\mathrm{CH}$ include antimicrobial activity (2-5), mechanical blocking to avoid re-infection of the root canal $(5,6)$, capacity to limit root resorption $(7,8)$, induces formation of mineralized tissue $(5,6)$ and promotes repair of periapical and adjacent tissues $(2,4)$.

The antimicrobial activity and capacity to limit root resorption are related to the alkalinizing action of calcium hydroxide, which in turn is a consequence of its ionization into hydroxyl ions (7-9). Tronstad et al. (8) suggested that $\mathrm{CH}$ in the root canals promotes a $\mathrm{pH}$ increase on the external root surface, thus promoting alkalinization of resorption areas on the root surface, by diffusion of hydroxyl ions through the dentinal tubules. Other important characteristic of the dissociation of $\mathrm{CH}$ into hydroxyl ions is the ability to inactivate bacterial lipopolysaccharide (LPS), a toxin produced by Gram-negative bacteria commonly found in the root canal system $(4,6)$.

When applied inside the root canal, $\mathrm{CH}$ must be able to diffuse through the apical foramen, ramifications, secondary and accessory canals, as well as through the dentinal tubules, reaching areas of root resorption, areas contaminated by microorganisms and adjacent tissues, to promote its action $(4,8,10)$.
Different vehicles are added to improve the qualities

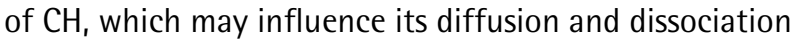
through the root canal system $(5,6,10,11)$. The vehicle used for this association should allow efficient dissociation of hydroxyl ions for a satisfactory action of $\mathrm{CH}(2,4,12,13)$. Also, the vehicle may increase the antimicrobial capacity of the paste and aid the periapical repair process (12). Sterile distilled water, saline, propylene glycol, camphorated paramonochlorophenol, glycerin, anesthetic solutions, chlorhexidine, propolis and other substances have been frequently used as vehicles for $\mathrm{CH}$ pastes $(1,2,5,6,10,12-17)$. Several combinations have been investigated to determine the effectiveness of $\mathrm{CH}$ pastes $(2,10)$.

Aloe vera is a plant from the liliacea family commonly known as "babosa". It is a cactus with thorny lance-shaped green leaves and growing fast in warm and dry weather $(18,19)$. After extraction of gel from its leaves, it has been therapeutically used in ancient and modern cultures throughout the world due to its great reputation as a healing and anti-inflammatory agent. Thus, it presents wide utilization in the health, food and cosmetic fields (1820). Several studies with Aloe vera have demonstrated its positive qualities in relation to healing (18), antimicrobial activity (21), formation of mineralized barrier in pulp capping (22), antifungal activity and anti-inflammatory properties against lipoxygenase and COX-2 (23). Also, a study conducted on acemannan, a mucopolysaccharide extracted from the Aloe vera leaf gel, demonstrated that 
this substance plays a significant role in the healing process of oral wounds, by induction of fibroblast proliferation and stimulation of keratinocyte growth factor-1 (KGF-1), vascular endothelial growth factor (VEGF) and expression of type I collagen (24).

After confirming the antimicrobial capacity and biocompatibility of the Aloe vera gel, its use as vehicle for the $\mathrm{CH}$ paste may be considered. Therefore, it is of interest to determine the diffusion of hydroxyl ions of this paste through the dentinal tubules, which is fundamental for the action of a $\mathrm{CH}$ paste.

This study evaluated the diffusion of hydroxyl ions through the dentinal tubules from different $\mathrm{CH}$ pastes containing Aloe vera. The tested hypothesis is that the pastes containing Aloe vera diffuse through the dentinal tubules.

\section{Materials and Methods}

\section{Ethical Aspects}

The study was approved by the Institutional Review Board in Animal Studies - CEUA of Araçatuba School os Dentistry, UNESP (Process \#02390-2011).

\section{Experimental Design}

The study was conducted on 60 extracted singlerooted bovine teeth, with single and straight root canals. The soft tissues, root cementum and calculi adhered to the root surface were removed with periodontal curettes, avoiding damage to the external surface. The crowns were transversally sectioned by a carborundum disc (Dentorium International, New York, NY, USA) in a low-speed handpiece, at approximately 12,000 rpm (KaVo Dental, Charlotte, NC, USA), irrigated with distilled water, standardizing the root length at $20 \mathrm{~mm}$. Teeth that showed enlarged root canal ( $\mathrm{K}$ file $>\# 20$ ) were discarded.

The total root canal length was measured by introduction of a size $30 \mathrm{~K}$-file (Maillefer Instruments, Ballaigues, Switzerland) with a rubber stop. When the file tip crossed the apical foramen, the stop was placed on the cervical edge of the root and the length was recorded. The working length was established by subtracting $1 \mathrm{~mm}$ from the total root canal length. Roots with working length lower than $19 \mathrm{~mm}$ were discarded and replaced.

Biomechanical preparation was performed up to the predetermined limit and the apical end was prepared up to a size $80 \mathrm{~K}$-file with stepback up to size $120 \mathrm{~K}$-file. During instrumentation, the root canals were irrigated with $2.5 \%$ $\mathrm{NaOCl}$ at each change of file.

After biomechanical preparation, a size $30 \mathrm{~K}$-file was introduced up to the total root canal length to clean the apical foramen. The root canals were dried with absorbent paper points (Tanariman Industrial Ltda, Manacapuru, AM,
Brazil), filled with 17\% EDTA for 3 min and then rinsed with saline and dried again with absorbent paper points.

The teeth were randomly divided in 4 groups $(n=15)$ according to the root canal dressing pastes prepared by mixing $\mathrm{CH}$ powder with different vehicles: Group $\mathrm{CH} / \mathrm{S}$ (control paste): $1 \mathrm{~g} \mathrm{CH}$ plus $1.5 \mathrm{~mL}$ saline; Group $\mathrm{CH} / \mathrm{P}$ (control paste): $1 \mathrm{~g} \mathrm{CH}$ plus $2 \mathrm{~mL}$ propylene glycol; Group $\mathrm{CH} / \mathrm{A}$ (experimental paste 1): $1 \mathrm{~g} \mathrm{CH}$ plus $1 \mathrm{~mL}$ Aloe vera gel; Group CH/A/P (experimental paste 2): $1 \mathrm{~g} \mathrm{CH}, 1 \mathrm{~g}$ Aloe vera powder and $2 \mathrm{~mL}$ propylene glycol.

The placement of the intracanal medicaments was performed by a manual lentulo spiral (Dentsply). After filling the root canals completely with the pastes, the root canal openings were sealed with temporary sealer (Coltosol; Vigodent SA Indústria e Comércio, Rio de Janeiro, RJ, Brazil). Thereafter, the apical foramen and openings (over the interim sealer) were sealed with a two-step epoxy adhesive. The teeth were placed in flasks containing $30 \mathrm{~mL}$ deionized water and kept in an oven at $37{ }^{\circ} \mathrm{C}$ with $100 \%$ humidity.

After 3 h, 24 h, 72 h, 7 days, 15 days and 30 days, the $\mathrm{pH}$ values of solutions in the flasks were measured using a pH meter (Hanna Instruments Brasil, São Paulo, SP, Brazil), previously calibrated for each group, using standardized buffer solutions with pH 4.0 (acetic acid) and 7.0 (sodium acetate). For each measurement, the $\mathrm{pH}$ meter electrode was carefully rinsed with deionized water and dried with absorbent paper to eliminate residues that might interfere with the measurements.

\section{Statistical Analysis}

Analysis of variance was performed to test differences between experimental groups and the analyzed time periods. Tukey's post-hoc test was used to analyze significant results. Values of $p<0.05$ were considered statistically significant.

\section{Results}

Figure 1 presents the $\mathrm{pH}$ variation in relation to the time periods for the different pastes. The values indicate the means obtained for each period, considering the 15 measurements obtained for each group. The details of the means and standard deviation obtained may be seen in Table 1.

In Group $\mathrm{CH} / \mathrm{S}$, the highest $\mathrm{pH}$ value was observed at periods of 3 and $24 h$, being lower at other periods $(p<0.05)$. There was a significant decrease in $\mathrm{pH}$ between 24 and 72 $\mathrm{h}$, yet after this period the $\mathrm{pH}$ values remained stable in relation to the value at $24 \mathrm{~h}$, up to 30 days.

In Group $\mathrm{CH} / \mathrm{P}$, the highest $\mathrm{pH}$ value was observed in periods of $3 h$, being lower in other periods $(p<0.05)$. There was significant reduction in $\mathrm{pH}$ between $24 \mathrm{~h}$ and 15 days, yet at 30 days the $\mathrm{pH}$ value increased significantly 
in relation to the other periods, except for $3 \mathrm{~h}(\mathrm{p}<0.05)$.

In Group $\mathrm{CH} / \mathrm{A}$, the highest $\mathrm{pH}$ values were observed in periods of $3 h, 15$ days and 30 days $(p<0.05)$. Significant ion release was observed at $3 \mathrm{~h}$, which reduced up to 7 days and increased again at 15 days.

In Group $\mathrm{CH} / \mathrm{A} / \mathrm{P}$, highest $\mathrm{pH}$ values were observed at 24 and $72 h(p<0.05)$. There was lower ion release at $3 h$, which increased in periods of 24 and $72 \mathrm{~h}$, reducing at 7 days and remaining stable thereafter up to 30 days.

Comparison of the study groups evidenced greater ion release at $3 \mathrm{~h}$ in Groups $\mathrm{CH} / \mathrm{S}$ and $\mathrm{CH} / \mathrm{P}(\mathrm{p}<0.05)$. At $24 \mathrm{~h}$, Groups $\mathrm{CH} / \mathrm{S}$ and $\mathrm{CH} / \mathrm{A} / \mathrm{P}$ presented higher $\mathrm{pH}$ values, with significantly higher $\mathrm{pH}$ in Group $\mathrm{CH} / \mathrm{A} / \mathrm{P}$ compared to the other groups ( $\mathrm{p}<0.05)$. At $72 \mathrm{~h}$, Group CH/A/Pstill presented higher $\mathrm{pH}$ than the other groups. At 7 days, the highest $\mathrm{pH}$ was observed for Group $\mathrm{CH} / \mathrm{S}$, followed by Group $\mathrm{CH} / \mathrm{A} / \mathrm{P}$. At 15 days, there was no difference in $\mathrm{pH}$ between Groups $\mathrm{CH} / \mathrm{S}, \mathrm{CH} / \mathrm{A}$ and $\mathrm{CH} / \mathrm{A} / \mathrm{P}$, with lowest $\mathrm{pH}$ values observed in Group CH/P. At 30 days, Group $\mathrm{CH} / \mathrm{S}$ had a more expressive $\mathrm{pH}$, without difference only with Group $\mathrm{CH} / \mathrm{A}$.

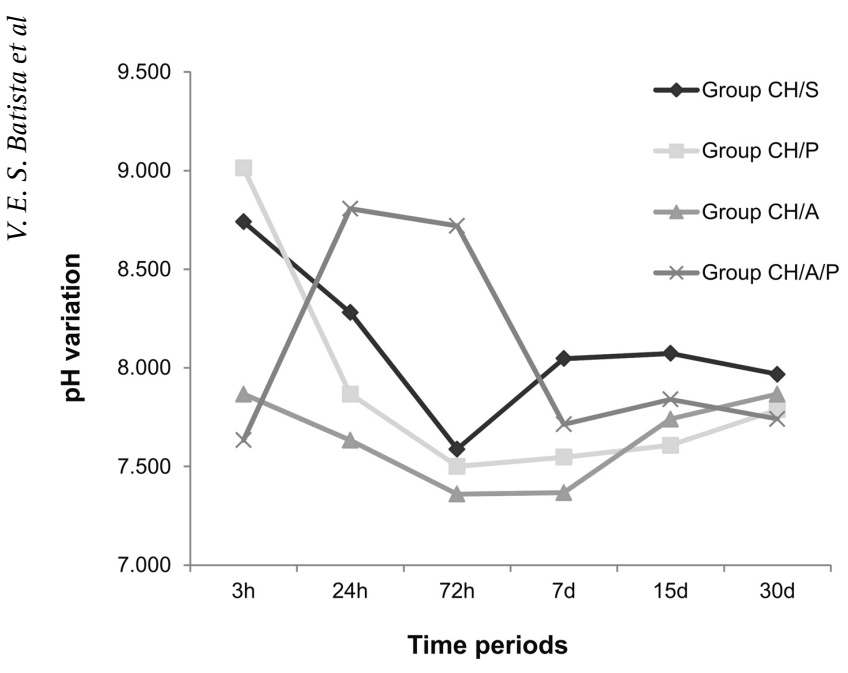

Figure 1. Variation of mean $\mathrm{pH}$ values according to the study periods, for the different study groups.

\section{Discussion}

The hypothesis was accepted since the results showed that the pastes containing Aloe vera may diffuse through the dentinal tubules.

Due to the wide use of $\mathrm{CH}$ as intracanal medication, several studies have addressed its diffusion in the dentinal tubules $(3,13,17)$. The diffusion of $\mathrm{CH}$ through the apical foramen, ramifications and dentinal tubules is fundamental to eliminate the contamination, inhibit root resorption and induce apical and periapical repair $(4,10,25)$.

Different vehicles have been added to $\mathrm{CH}$ powder for preparation of pastes $(13,25)$. These associations aim to facilitate the use of $\mathrm{CH}$, improve the antimicrobial capacity, enhance the ion diffusion through the dentinal tubules, aid in radiopacity, biocompatibility and texture of the material $(2,10)$. In this context, the beneficial qualities of the Aloe vera $(18,22)$ when associated with $\mathrm{CH}$ may increase the apical and periapical repair. However, other studies should be performed to obtain better understanding.

In the search for a better antimicrobial capacity of $\mathrm{CH}$ against resistant microorganisms, especially against $E$. faecalis, new vehicles have been investigated, including chlorhexidine $(5,25)$ and propolis $(17)$.

Similar to the studies of Mori et al. (25) and Montero and Mori (17), this investigation demonstrated that the saline and propylene glycol pastes diffused through the dentinal tubules, in which similar levels were observed in both groups, confirming indication of these substances as vehicles for $\mathrm{CH}$ paste.

Considering that the efficacy of these substances (saline and propylene glycol) has been demonstrated in the literature as vehicles for $\mathrm{CH}$, they were used as reference groups for comparisons in this study. Thus, they showed an effective dissociation of hydroxyl ions in the first hours as described in literature $(10,16,25)$. Furthermore, after 30 days, both pastes exhibited a similar diffusion of hydroxyl ions to the external root surface (17).

Because of its antimicrobial capacity (21) and beneficial qualities considering the need of repair $(18,22)$, Aloe vera

Table 1. Means and standard deviations of $\mathrm{pH}$ variation with time in all groups

\begin{tabular}{|c|c|c|c|c|c|c|}
\hline \multirow{2}{*}{ Group } & \multicolumn{6}{|c|}{ Time } \\
\hline & $3 \mathrm{~h}$ & $24 \mathrm{~h}$ & $72 \mathrm{~h}$ & 7 days & 15 days & 30 days \\
\hline $\mathrm{CH} / \mathrm{S}$ & $8.740^{\mathrm{a}}(0.316)$ & $8.280^{c}(0.425)$ & $7.587^{\mathrm{b}, \mathrm{d}}(0.436)$ & $8.047^{b}(0.610)$ & $8.073^{b}(0.718)$ & $7.967^{\mathrm{b}}(0.216)$ \\
\hline $\mathrm{CH} / \mathrm{P}$ & $9.013^{a}(0.376)$ & $7.867^{\mathrm{b}, \mathrm{c}}(0.299)$ & $7.500^{\mathrm{b}, \mathrm{d}, \mathrm{e}}(0.210)$ & $7.547^{\mathrm{b}, \mathrm{d}}(0.064)$ & $7.607^{\mathrm{b}, \mathrm{d}}(0.175)$ & $7.787^{\mathrm{b}, \mathrm{f}}(0.151)$ \\
\hline $\mathrm{CH} / \mathrm{A}$ & $7.867^{\mathrm{a}}(0.364)$ & $7.633^{b, c}(0.145)$ & $7.360^{\mathrm{b}, \mathrm{d}, \mathrm{e}}(0.112)$ & $7.367^{\mathrm{b}, \mathrm{d}, \mathrm{g}}(0.140)$ & $7.740^{\mathrm{f}, \mathrm{h}}(0.199)$ & $7.867^{\mathrm{d}, \mathrm{f,h}}(0.135)$ \\
\hline $\mathrm{CH} / \mathrm{A} / \mathrm{P}$ & $7.633^{\mathrm{a}}(0.264)$ & $8.807^{\mathrm{b}, \mathrm{c}}(0.252)$ & $8.720^{\mathrm{b}, \mathrm{c}}(0.511)$ & $7.713^{\mathrm{b}, \mathrm{d}}(0.136)$ & $7.840^{\mathrm{d}}(0.223)$ & $7.740^{\mathrm{d}}(0.184)$ \\
\hline
\end{tabular}

Statistically significant difference $(p<0.05): a, b ; c, d ; e, f$. 
has been suggested in association with $\mathrm{CH}$. Therefore, this study was conducted to investigate the influence of Aloe vera on the diffusion of hydroxyl ions through the dentinal tubules.

Since Aloe vera is available both as powder and gel, it was interesting to analyze both presentations, thus two Aloe vera groups were constituted. In the stage of paste preparation, Group $\mathrm{CH} / \mathrm{S}$ evidenced need of constant handling to enhance its insertion and paste texture after mixing, complicating its insertion in the root canal. Group $\mathrm{CH} / \mathrm{P}$ presented easy mixing, viscous texture after mixing, and good insertion in the root canal. Group $\mathrm{CH} / \mathrm{A}$ exhibited easy mixing, viscous texture after mixing and good insertion in the root canal. Group $\mathrm{CH} / \mathrm{A} / \mathrm{P}$ presented difficult mixing, sticky texture after mixing and good insertion in the root canal. The pastes in Groups $\mathrm{CH} / \mathrm{S}, \mathrm{CH} / \mathrm{P}, \mathrm{CH} / \mathrm{A}$ presented white color and the paste in Group $\mathrm{CH} / \mathrm{A} / \mathrm{P}$ exhibited a dark brown color, which evidenced the need for more careful cleaning of the pulp chamber. All pastes were present in the root canals at 30 days after the study. The teeth in Group $\mathrm{CH} / \mathrm{A} / \mathrm{P}$ presented discoloration.

According to the present results, the experimental paste 1 (Group $\mathrm{CH} / \mathrm{A})$ diffused constantly through the dentinal tubules, reaching the external root surface. The experimental paste 2 (Group CH/A/P) presented the highest $\mathrm{pH}$ at 24 and $72 \mathrm{~h}$, suggesting its use as a fast action medication. The $\mathrm{pH}$ increase of Group $\mathrm{CH} / \mathrm{A} / \mathrm{P}$ may be associated to the propylene glycol which is related to the greatest diffusion of hydroxyl ions in the first hours (17). However, the Group CH/P did not show these values, suggesting that Aloe vera facilitated diffusion through the dentinal tubules. Therefore, further studies addressing the biocompatibility and antimicrobial action of experimental pastes are indicated to determine their utilization.

In conclusion, based on the outcomes of this in vitro study, experimental pastes containing Aloe vera were able to enable the diffusion of hydroxyl ions through the dentinal tubules. The $\mathrm{CH}$, Aloe vera and propylene glycol paste (Group $\mathrm{CH} / \mathrm{A} / \mathrm{P}$ ) presented the highest $\mathrm{pH}$ at 24 and 72 h. After 30 days, all of the studied pastes presented similar diffusion of hydroxyl ions through the dentin.

\section{Resumo}

Este estudo avaliou a difusão de íons hidroxila de diferentes pastas de hidróxido de cálcio contendo Aloe vera através dos túbulos dentinários. Foram utilizados 60 dentes bovinos unirradiculares. As coroas dos dentes foram removidas, os canais radiculares foram instrumentados e divididos em 4 grupos $(n=15)$ de acordo com a medicação intracanal: Grupo HC/ SF - pasta de hidróxido de cálcio e soro fisiológico; Grupo HC/P - pasta de hidróxido de cálcio e propilenoglicol; Grupo HC/A - pasta de hidróxido de cálcio e Aloe vera gel; Grupo HC/A/P - pasta de hidróxido de cálcio, propilenoglicol e Aloe vera. Após o preenchimento dos canais radiculares com as respectivas pastas, os dentes foram selados coronalmente e na região do ápice radicular com adesivo epóxi. Os dentes foram colocados em frascos identificados contendo água deionizada e armazenados em estufa, com $100 \%$ de umidade, a $37^{\circ} \mathrm{C}$. Após $3 \mathrm{~h}, 24 \mathrm{~h}, 72 \mathrm{~h}, 7$ dias, 15 dias e 30 dias, a água deionizada dos frascos foi coletada e realizada a medição do $\mathrm{pH}$ com auxílio de um pHmetro. Os dados obtidos foram submetidos à análise estatística, com grau de significância de 5\%. Os resultados mostraram que todas as pastas estudadas promoveram a difusão dos íns hidroxila através dos túbulos dentinários. A associação do Aloe vera ao $\mathrm{HC}$ (grupo HC/A) resultou em uma liberação de forma constante de íns cálcio. $\mathrm{O}$ grupo HC/A/P mostrou o $\mathrm{pH}$ mais elevado que as demais pastas em 24 e 72 horas. Concluiu-se que as pastas experimentais contendo Aloe vera foram capazes de permitir a difusão de íons hidroxila através dos túbulos dentinários.

\section{Acknowledgements}

The authors would like to express their gratitude to the São Paulo Research Foundation - FAPESP, Brazil (2011/20257-0).

\section{References}

1. Victorino FR, Bramante CM, Zapata RO, Casaroto AR, Garcia RB, Moraes $I G$, et al. Removal efficiency of propolis paste dressing from the root canal. J Appl Oral Sci 2010;18:621-624.

2. Fava $L R$, Saunders WP. Calcium hydroxide pastes: classification and clinical indications. Int Endod J 1999;32:257-282.

3. Safavi KE, Nichols FC. Alteration of biological properties of bacterial lipopolysaccharide by calcium hydroxide treatment. J Endod 1994;20:127-129.

4. Duarte MA, Demarchi AC, Giaxa MH, Kuga MC, Fraga SC, de Souza LC. Evaluation of $\mathrm{pH}$ and calcium ion release of three root canal sealers. J Endod 2000;26:389-390.

5. Vianna ME, Zilio DM, Ferraz CC, Zaia AA, de Souza-Filho FJ, Gomes BP. Concentration of hydrogen ions in several calcium hydroxide pastes over different periods of time. Braz Dent J 2009;20:382-388.

6. Silveira CF, Cunha RS, Fontana CE, de Martin AS, Gomes BP, Motta RH, et al.. Assessment of the antibacterial activity of calcium hydroxide combined with chlorhexidine paste and other intracanal medications against bacterial pathogens. Eur J Dent 2011;5:1-7.

7. Guerreiro-Tanomaru JM, Chula DG, de Pontes Lima RK, Berbert FL, Tanomaru-Filho M. Release and diffusion of hydroxyl ion from calcium hydroxide-based medicaments. Dent Traumatol 2012;28:320-323.

8. Tronstad L, Andreasen JO, Hasselgren G, Kristerson L, Riis I. pH changes in dental tissues after root canal filling with calcium hydroxide. J Endod $1981 ; 7: 17-21$

9. Siqueira JF Jr, Lopes HP. Mechanisms of antimicrobial activity of calcium hydroxide: a critical review. Int Endod J 1999;32:361-369.

10. Zmener 0 , Pameijer $\mathrm{CH}$, Banegas $\mathrm{G}$. An in vitro study of the $\mathrm{pH}$ of three calcium hydroxide dressing materials. Dent Traumatol 2007;23:21-25.

11. de Rezende GP, da Costa LR, Pimenta FC, Baroni DA. In vitro antimicrobial activity of endodontic pastes with propolis extracts and calcium hydroxide: a preliminary study. Braz Dent J 2008;19:301-305.

12. Simon ST, Bhat KS, Francis R. Effect of four vehicles on the $\mathrm{pH}$ of calcium hydroxide and the release of calcium ion. Oral Surg Oral Med Oral Pathol Oral Radiol Endod 1995;80:459-464.

13. Pacios MG, de la Casa ML, de los Angeles Bulacio M, López ME. Calcium hydroxide's association with different vehicles: In vitro action on some dentinal components. Oral Surg Oral Med Oral Pathol Oral Radiol Endod 2003;96:96-101.

14. Semenoff TA, Semenoff Segundo A, de Figueiredo JA. Biocompatibility of different intracanal medications in rat bucal submucosa tissue. J Appl Oral Sci 2008;16:12-17.

15. Oliveira JC, Alves FR, Uzeda Md, Rôças IN, Siqueira JF Jr. Influence of serum and necrotic soft tissue on the antimicrobial effects of intracanal medicaments. Braz Dent J 2010;21:295-300.

16. Estrela C, Sydney GB, Pesce HF, Felippe Júnior 0. Dentinal diffusion of hydroxyl ions of various calcium hydroxide pastes. Braz Dent J 1995;6:5-9.

17. Montero JC, Mori GG. Assessment of ion diffusion from a calcium hydroxide-propolis paste through dentin. Braz Oral Res 2012;26:318-322. 
18. Maenthaisong R, Chaiyakunapruk N, Niruntraporn S, Kongkaew C. The efficacy of Aloe vera used for burn wound healing: a systematic review. Burns 2007;33:713-718.

19. Vogler BK, Ernst E. Aloe vera: a systematic review of its clinical effectiveness. Br J Gen Pract 1999;49:823-828.

20. Habeeb F, Shakir E, Bradbury F, Cameron P, Taravati MR, Drummond $A J$, et al.. Screening methods used to determine the anti-microbial properties of Aloe vera inner gel. Methods 2007;42:315-320.

21. Pandey R, Mishra A. Antibacterial activities of crude extract of Aloe barbadensis to clinically isolated bacterial pathogens. Appl Biochem Biotechnol 2010;160:1356-1361.

22. Jittapiromsak N, Sahawat D, Banlunara W, Sangvanich P, Thunyakitpisal P. Acemannan, an extracted product from Aloe vera, stimulates dental pulp cell proliferation, differentiation, mineralization, and dentin formation. Tissue Eng Part A 2010;16:1997-2006.
23. Das S, Mishra B, Gill K, Ashraf MS, Singh AK, Sinha M, et al.. Isolation and characterization of novel protein with anti-fungal and antiinflammatory properties from Aloe vera leaf gel. Int J Biol Macromol 2011;48:38-43.

24. Jettanacheawchankit $S$, Sasithanasate $S$, Sangvanich $P$, Banlunara W, Thunyakitpisal P. Acemannan stimulates gingival fibroblast proliferation; expressions of keratinocyte growth factor-1, vascular endothelial growth factor, and type I collagen; and wound healing. $J$ Pharmacol Sci 2009;109:525-531.

25. Mori GG, Ferreira FC, Batista FR, Godoy AM, Nunes DC. Evaluation of the diffusion capacity of calcium hydroxide pastes through the dentinal tubules. Braz Oral Res 2009;23:113-118.

Received Mach 18, 2014 Accepted June 2, 2014 